\title{
DOTHIDIACEOUS AND OTHER PORTO RICAN FUNGI
}

\author{
F. L. STEVENS
}

\section{(WITH PLATES XIII, XIV AND THREE FIGURES)}

The following fungi were collected by the author in Porto Rico, and specimens are deposited in the herbarium of the University of Illinois, and of the New York Botanical Garden. The limitations accepted for the Dothidiaceous genera are those of THEISSEN and SyDow, ${ }^{\mathrm{I}}$ which seem to be well founded and wholly tenable.

\section{Dothideales}

\section{DOTHIDEACEAE}

\section{Auerswaldia Cecropiae P. Henn. (figs. 4, 5).}

On Cecropia peltata: El Alto de le Bandera, 9043; Mayaguez, 3931; Maricao, 8965; Rio Arecibo, 7798; Florida Adentro, 7756, 2475; Jayuya, 36r; Añasco, 358r; Utuado, 6064 .

This fungus, as the number of collections shows, is abundant in Porto Rico. From descriptions it seems to be the one just named. It is very variable in habit, especially with age, and there is some doubt as to its generic position. In young specimens there is no stroma, and the fungus appears Sphaeriaceous. In older specimens the stroma is well developed, and the fungus is clearly Dothidiaceous. No colored spores were seen, and the fungus to all appearances is really a Phyllachorella. Type material of $A$. Cecropiae P. Henn. and Physalospora Cecropiae Rehm are needed before a satisfactory decision can be made.

Uleodothis Pteridis, sp. nov. (figs. 6, 7).-Spots tan-colored, dead, $3-5 \mathrm{~mm}$. across. Stromata black, rugose with perithecia, I-2 mm. across, conspicuous above, less so below, slightly raised above the leaf surface, orginating sub-epidermally but eventually occupying the whole mesophyll, the upper surface rough and raised, without clypeus, and remaining covered by fragments of the epidermis. Hyphae of the stroma of general parallel arrangement. Loculi many, about $100 \mu$ in diameter, globular. Asci

${ }^{x}$ Ann. Mycol. 13:149. I915. 
numerous, $65 \times \mathrm{I}_{4} \mu$, cylindrical, 4 -spored. Paraphyses few, inconspicuous, fine, filamentous. Spores hyaline, 2-celled, oblong, I $7-20 \times 4-5 \mu$.

On Pteridium caudatum, Maricao, $48 \mathrm{I}_{4}$ (type), $\mathrm{I}_{67}$.

This fungus agrees somewhat closely with Dothidella pteridophila Speg., but differs essentially in that it has paraphyses, and the asci are 4-spored. It differs from Uleodothis, as described, in having 4 -spored asci, but it does not seem wise to found a new genus merely on this character.

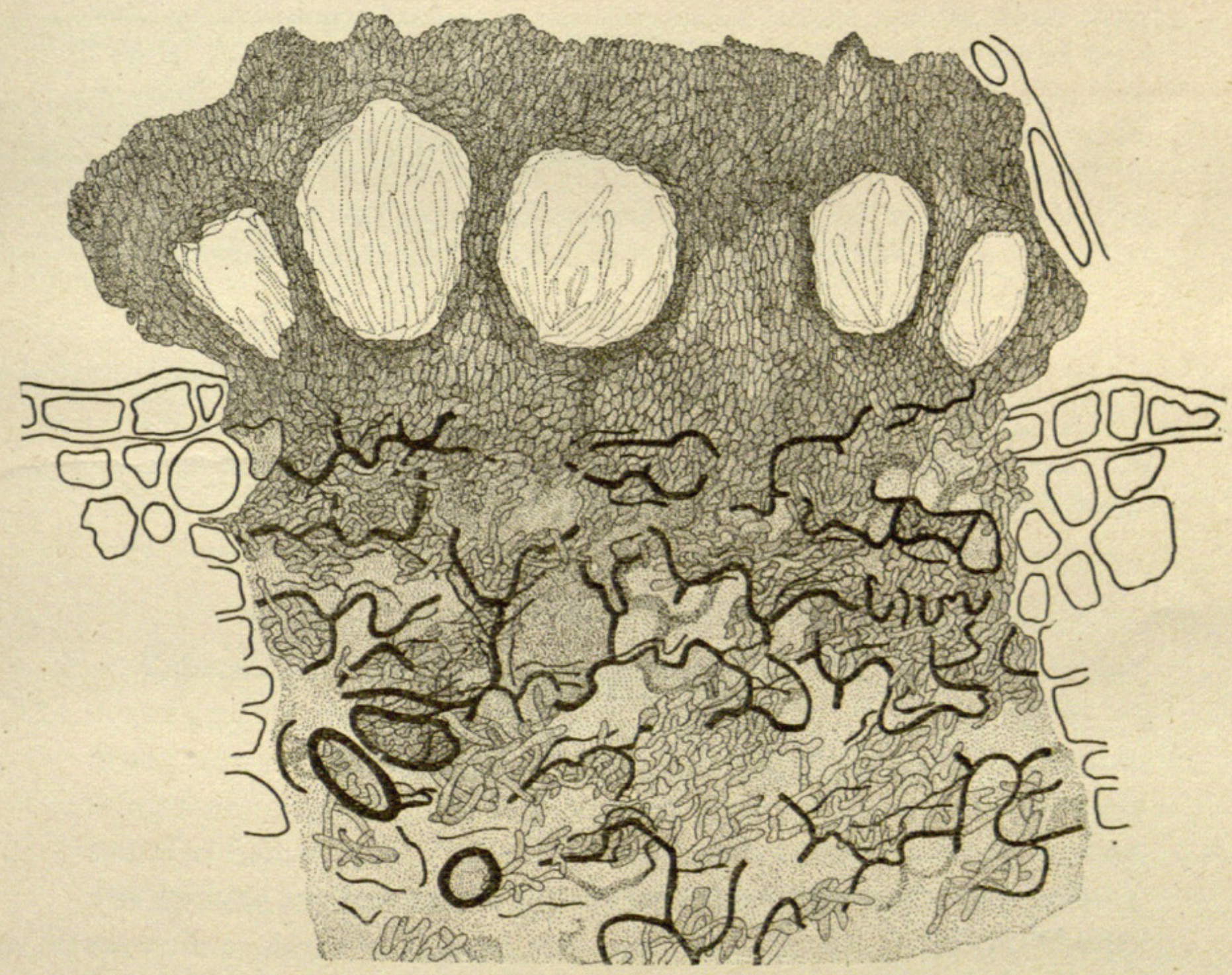

FIG. 1.-Structure of stroma and arrangement of locules

Dothidella portoricensis, sp. nov. (figs. 8, 9; text fig. I).-Spots linear, $0.5^{-\mathrm{I}} \times 3^{-4} \mathrm{~mm}$., amphigenous, definite. Stromata linear, entirely occupying the spots, raised above the leaf surface about $70 \mu$. Perithecial cavities in about 5 rows, nearly globular, about $70 \mu$ in diameter. Paraphyses none. Asci numerous, cylindrical, $54 \times$ ıо $\mu, 8$-spored. Spores hyaline to dilute smoky, I-septate, I $7 \times 3.5 \mu$. 
On Gleichenia, Las Marias, 3551, x.62 (type).

The stromata differ essentially in shape from those of $D$. pteridophila Speg. (fig. I).

Dothidella flava, sp. nov. (text figs. 2, 3).- Stromata pale to yellow, circular when young, linear when old; when mature, I $600 \mu$ long by $270 \mu$ wide, subepidermal, later erumpent, rising to considerable height above the leaf surface. Perithecial locules

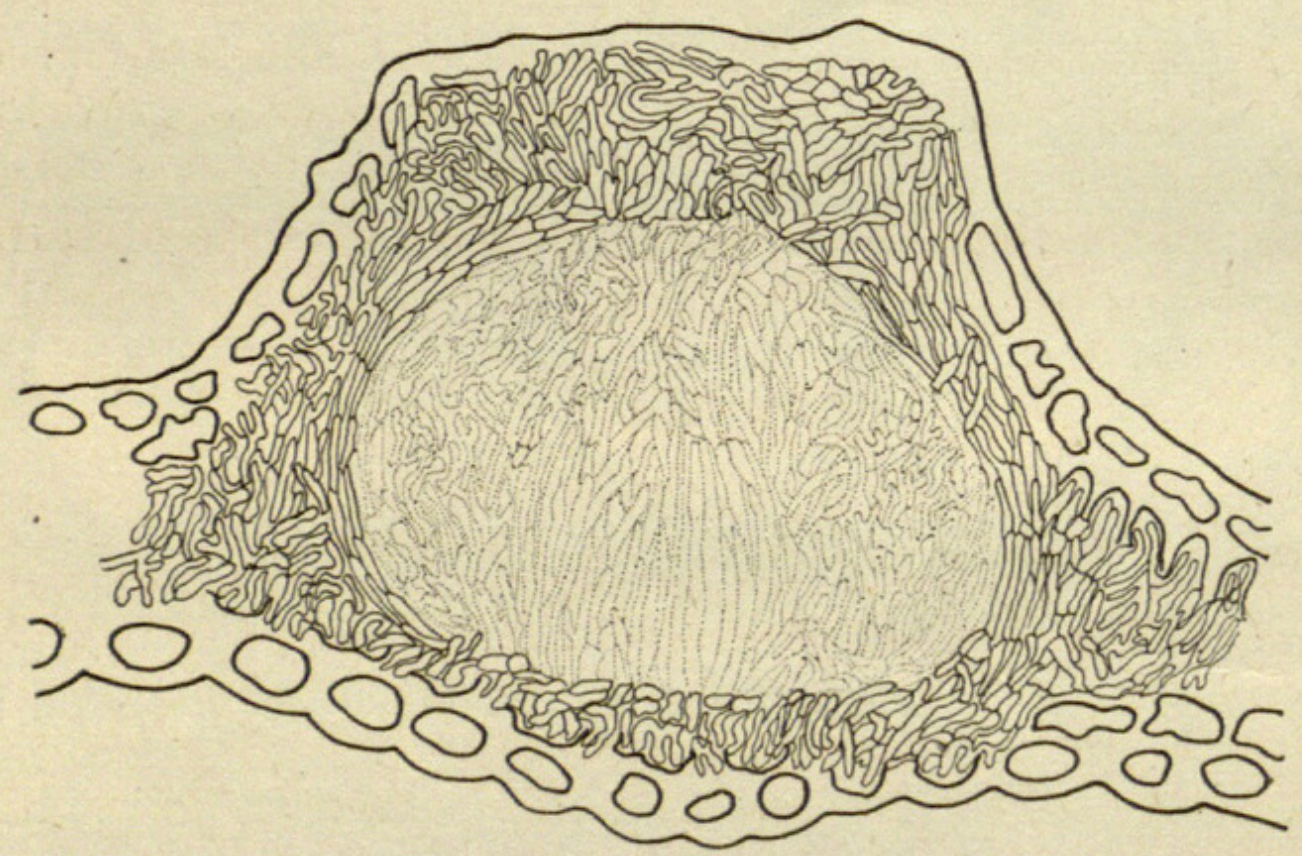

FIG. 2

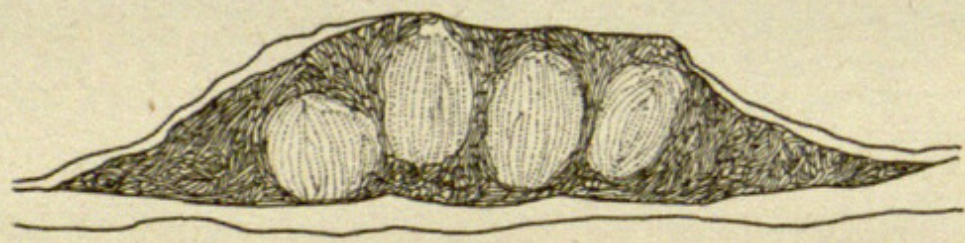

FIG. 3

Figs. 2, 3.-Cross and long sections showing arrangement and shape of perithecia and pycnidia.

globular, 60-70 $\mu$ in diameter, arranged in one or two rows in the stromata. Asci linear, 8-spored, 34-5r $\times 6 \mu$. Spores hyaline, 2-celled, oblong, $3.5 \times 14 \mu$. Conidia filamentous, $40 \times 1.5 \mu$, hyaline, borne in the same stromata with the perithecia and preceding them, and either free in an acervulus or in pycnidial locules in the stroma.

On Lithachne pauciflora: Trujillo Alto, 9394, 7654; Mayaguez, 1062, 7432; Florida Adentro, 7665 (type), 7650. 
This fungus is particularly interesting. To the naked eye it is like a rust. Superficial microscopic examination shows circular conidial sori which on casual observation might pass as a Cylindrosporium. Intermingled with the circular sori are many linear sori and stromata, all bearing the Septorialike conidia in great numbers. Microtome sections show that all development is subepidermal. The first locule is conidiiferous, and is so thin-walled that the wall might easily be overlooked. The sorus elongates, ruptures the epidermis, and in section takes on the appearance shown in text fig. 3. At about this period perithecial locules appear with asci and spores. Their walls are indistinguishable from the surrounding stroma, and the whole structure is truly Dothideaceous. The stromata are frequently overgrown by a Helminthosporium. Following TheIssen and Sydow, it belongs to the Dothideaceae, falling in the genus Dothidella. To many it may appear more reasonable to put it in the Hypocreales on account of its color; but it appears to me to show much closer relationship with the Dothideaceae, notwithstanding its pale color.

\section{Phyllachoraceae}

Trabutia Randiae (Rehm.) Th. and Syd.

On Randia aculeata, Cabo Rojo, 6455.

This fungus is clearly a Trabutia with strictly subcuticular stroma, and as it agrees well with the published description of $T$. Randiae, it is in all probability that species.

\section{SCIRRHIINEAE}

Catacauma Ocoteae, sp. nov.-Spots irregularly circular, $0.5^{-1} \mathrm{~cm}$. or more in diameter, visible from above or below on dead, tan-colored tissue, border indefinite. Stromata circular, numerous, scattered throughout the spot, plane above, strongly rounded below, I-I. $5 \mathrm{~mm}$. in diameter, between the lower epidermis and the mesophyll. Clypeus hypophyllous, rarely epiphyllous, extending slightly beyond the perithecia, very thick (60-I Iо $\mu$ ). Locules several, large (about $300 \mu$ in diameter), irregular. Asci 4-8-spored, $85^{-102} \times 7 \mu$ long, slender, with long sterile base. Spore I-celled, hyaline, oblong, $\mathrm{I}_{4}-20 \times 3.5 \mu$. Paraphyses filiform.

On Ocotea leucoxylon, Monte Alegrillo, 4725 (type), 732, 1347 .

Entirely distinct from Phyllachora ocoteicola, although often upon the same leaf.

Catacauma palmicola, sp. nov. (figs. IO-I2).-Stromata conspicuous above, few below, black, shining, oval, I- $6 \times \mathrm{I}^{-3} \mathrm{~mm}$., 
with rounded surface, scattered and separate or clustered and confluent. Diseased area extending through the leaf, brown below. Stroma developing between epidermis and palisade cells, often $300 \mu$ thick. Locules irregular in shape, often 500-600 $\mu$ wide, basal layer hyaline, thin, lateral walls brown, thick; clypeus black, 60-100 $\mu$ thick. Asci numerous, 8-spored, saccate, thinwalled. Spores inordinate, cylindrical, $28-43 \times$ I 2-I4 $\mu$, hyaline, continuous.

On Thrinax ponceana, Vega Baja, 77ı6 (type).

Catacauma urbanianum (A. and H.) Th. and Syd. (fig. I3). On Calyptranthes Krugii: El Yunque, 8243; Maricao, 3677, 3740.

What appears to be the same fungus, although usually hypophyllous and showing a concentric arrangement of stromata, occurs on an unknown Myrtaceous host, no. 5766, San German. Another specimen from Monte Alegrillo, $45^{26}$, shows the characteristic acervuli and spores, but is mainly conidial. The Septoria-like conidia are borne in very large cavities in the stromata. The ascospores in these specimens are slightly longer $(17-20 \mu)$ and slightly thinner $(5 \mu)$ than called for by description.

Catacaumella Gouaniae, sp. nov. (figs. I4, I5).-Mainly epiphyllous, rarely hypophyllous. Spots barely exceeding the stromata, hardly visible below. Stromata abundant, roughly circular, 2-3 mm. in diameter, raised, wrinkled, shining black, developing between the epidermis and the palisade cells and made up of parallel cells perpendicular to the leaf surface. Loculi large, flat,

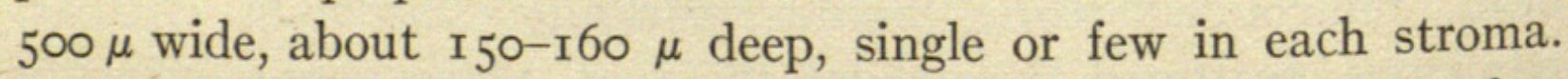
Ostiole very large and distinct. Asci thin-walled, irregular, 8-spored, 6I-68X Io-I $\mu$, inordinate. Spores hyaline, I-celled, ovoid or pyriform, irregular, $14-20 \times$ 10 $\mu$. Paraphyses none.

On Gouania polygana: Mayaguez, 3923 (type), I049; Salinas, 6798; Dos Bocas, 6007, 8092; Maricao, 8953; on Gouania lupuloides, Arecibo-Lares road, 7230 .

The last specimen shows the stromata smaller and more abundant upon the lower surface than is the case with the other specimens.

Phaeodothopsis Eupatorii, sp. nov. (figs. I6, I7).-Spot not exceeding the clypeus. Stromata numerous, circular, I-4 mm. in diameter, black, rough with perithecia, almost exclusively epiphyllous; developing first in the epidermis, producing an 
extensive clypeus, then developing the stromata between this clypeus and the palisade cells. Loculi globular or lenticulate, 100-250 $\mu$ in diameter, $80 \mu \mathrm{high}$, by pressure sometimes pushing into the mesophyll. Asci about I IоХ I $_{7} \mu$, cylindrical, 8-spored, inordinate. Spores $20 \times 7 \mu$, I-septate about one-third the distance from one end, brown when mature. Paraphyses filamentous, branching.

On Eupatorium portoricense, Dos Bocas below Utuado, 6866 (type), 6034, $6830,6437,686$ I, 6032, 6537 .

The clypeus is strictly epidermal, and under it very numerous loculi develop, each with an ostiole reaching through the clypeus. The occasional pressing of the perithecia into the mesophyll sometimes gives this the appearance of closer relationship to the Phyllachorineae, but its relationship is clearly with the Scirrhiineae.

Halstedia, gen. nov.-Asci borne in a locule in a superficial stroma.

Type $H$. Portoricensis. Named in honor of Byron D. Halsted.

Halstedia portoricensis, sp. nov. (figs. I8, I9).--Stromata amphigenous but more abundant and larger above, densely black, I-4 mm. in diameter, flat, with surface in the older parts corrugated, or sometimes raised in the center, strictly superficial, non-radiate. Perithecia up to $400 \mu$ in diameter, $\mathrm{I} 60 \mu$ from base to top, internal measurements. Asci 8-spored, $68-85 \times{ }_{4} 4 \mu$, cylindrical. Spores oval, continuous, hyaline or pale straw-colored, $17 \times$ io $\mu$.

On Sideroxylon foetidissimum, Quebradillos, 9239 (type).

The fungus consists of a densely black stroma which in the center is nearly $200 \mu$ in thickness, thinning at the edges to the thickness of the mycelium. The stroma is flat-topped, the bulging due to the development of the perithecium usually resulting in a downward thrust and displacement of the leaf rather than of the upper layer of the stroma (fig. I6). In some instances the reverse is true, with an upward bulging. Closest search failed to reveal any evidence of penetration of the fungus through the epidermis, or of any mycelium or signs of disease in any of the host cells. There is no ostiole, and the perithecium is poorly developed, if indeed it is more than a locule in the stroma. The fungus shows close kinship with the Dothideales, but cannot be placed in any of the families of that order as characterized by THEIssen and Sydow. It differs from typical Perisporiaceae in the absence of a clearly developed perithecium and in possessing a stroma. It forms an interesting transition form between these two groups, and may for the present be regarded as Perisporiaceous. 


\section{Perisporiales}

\section{Perisporiaceae}

Dimerina monenses, sp. nov. (fig. 20).-Epiphyllous, rarely hypophyllous, diffuse over the leaf surface. Mycelium superficial, scant, dark, irregular, $3 \mu$ thick with thinner side branches. No hyphopodia, perithecia rough, irregularly spherical, $45^{-60} \mu$ in diameter, without ostiole, arranged in close clusters of ro or more on a close dark subicle. Clusters ${ }^{5} 50-300 \mu$ in diameter. Asci numerous, elliptical, $34 \times{ }_{17} \mu$, obtuse, 8 -spored. Spores inordinate, hyaline or very pale-smoky, ${ }_{3}-16 \times_{3} \mu$, obtuse, 2 -celled.

On Jacquinia barbasco, Mona Island, 6087.

While the spores and asci agree well in size with those of Dimerina eutricha and $D$. negeriana, our species does not agree with these forms in other characters. Agreement as to asci and spores is close with Asterina paupercula E. and E., but our perithecium is not that of an Asterina.

\section{HysteritneaE}

Gloniella rubra, sp. nov. (fig. 2I).--Perithecia oblong, scattered, numerous, epiphyllous, black, $600-1500 \times 180-250 \mu$, opening by one or more longitudinal clefts; the perithecial contents thus exposed are red (near color no. I3 of Saccardo's scale). Asci longcylindrical, very crooked, especially at the tip, 8-spored, $85^{-9}{ }^{2} \times{ }_{10}$ $\mu$, inordinate. Paraphyses numerous, filiform, long. Spores hyaline or very faintly tinted, $\mathrm{I}-3$, mostly 3 -septate, fusoid, ${ }^{2} 3-26 \times 3 \mu$. (type).

On Arthrostylidium multispicatum Pilg., El Alto de la Bandera, 4363

This species is somewhat like $G$. pusilla Sacc., but differs from it in its carbonaceous perithecium, red contents, curved asci, etc.

\section{Pleosporaceae}

Physalospora Hoyae, v. Hohn. (fig. 22).

On Ficus, Mona Island, 6234, 6169.

This very pretty form I refer with some hesitancy to the preceding species. The spores in my specimen are uniseriate, and are considerably narrower than the description of von. HoHNEL calls for. P. elasticae Koord. is close kin, but differs in the rounded spores. Pycnidia are present, bearing slender filamentous spores, $7 \times 1 \mu$. 


\section{MycosPhaERELLACEAE}

Guignardia Justiciae, sp. nov. (figs. 23, 24).-Diseased spot indefinite, finally yellowish and pale, rather evenly beset with perithecia, I-2 mm. distant from each other. Perithecium globose, completely imbedded in the leaf, $26_{5} \mu$ in diameter and depth, its wall dark, several cells $(34 \mu)$ thick. Host tissue surrounding the perithecium hypertrophied to a distance of about I $25 \mu$ in every direction from the perithecium. The resulting "gall" is visible from either side of the leaf, and has the superficial appearance of a stroma with a single central perithecium. The ostiole develops late. Paraphyses none. Asci clavate, usually with a long stipe; body of ascus $\mathrm{I} 7-20 \times 6 \mathrm{I} \mu$; total length, including stipe, г $25 \mu$. Spores 8, inordinate, hyaline, I-celled, oval, 9-IOXI8 $\mu$.

On Justicia verticillaris: Maricao, 806 (type); El Yunque, 2839; El Gigante, 8557; El Alto de la Bandera, 9046.

This fungus is noteworthy on account of the peculiar gall-like formation surrounding each perithecium, the thick wall, and the peculiar long-stalked asci.

Guignardia Tetrazygiae, sp. nov.-Spots indefinite, irregular, $\mathrm{I}-2 \mathrm{~cm}$. in diameter or occupying the whole leaf, tan-colored, centers studded with the perithecia which are scattered evenly and profusely over the affected areas. Perithecia black, conspicuous both above and below, about $160 \mu$ in diameter, thickwalled. Asci, sporiferous part oval, $45 \times 27 \mu, 8$-spored, inordinate, stipe long, slender, $30-60 \times 4-5 \mu$. Paraphyses none. Spores I-celled, hyaline, oval, obtuse, $24 \times$ Io $\mu$.

On Tetrazygia sp.: San German, 4567 (type); Vega Alta, 4148.

This differs from Laestadia melastomalum (Lev.) Sacc. in the absence of paraphyses, shape of asci, and other characters. The leaf spot is very characteristic.

Guignardia Nectandrae, sp. nov.-Spots indefinite when young, becoming definite as the host tissue dies, then angular, $2-6 \mathrm{~mm}$. in diameter, showing from both sides of the leaf. Perithecia opening on both sides of the leaf, more abundant below, scattered, located in the mesophyll but causing swelling of both leaf surfaces. Perithecia thin-walled, pale, $70-85 \mu$ in diameter, 
located deep in the mesophyll. Asci clavate, Ioo-II $5 \times 20 \mu$, 8 -spored. Spores hyaline, oval, $2 \mathrm{I}-24 \times 8-10 \mu, 2$-celled, septa either in the middle or more frequently located near one end.

On Nectandra coriacea (?), Quebradillos, 4994 (type).

This fungus is of very distinctive appearance upon the leaves, where the erumpent perithecia so closely simulate a rust in appearance that the author was led to place it with the rusts on mere casual examination.

\section{SPHAERIACEAE}

Zignoella algaphila, sp. nov.-Mycelium fine, pale to brown, twining around and penetrating its algal host and turning it brown. Perithecia black, $90 \times 170-180 \mu$, variously formed but usually bottle-shapped, broadest a little above the base, with a prominent beak about $24 \mu$ in diameter and with the fibers arranged parallel around the ostiole. Surface coarsely reticulate but not hairy; basal portion appearing as though hairy due to adhering remnants of mycelium. Asci numerous, 8-spored, cylindrical, ${ }_{7 \mathrm{I}} \times{ }_{7} \dot{\mu}$. Paraphyses fine, threadlike. Spores hyaline, 3 -septate, pointed

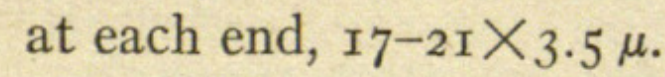

On' Cephaleuros virescens on Artocarpus incisa, Mayaguez, $5^{I}$ (type).

The parasitic alga when alone on this host is yellow or often nearly colorless, but when invaded by the Zignoella all the colonies take on a dark hue, giving the whole leaf much the appearance of being mildly affected with sooty mold. The genus Zignoella is large and composed mainly of wood-inhabiting saprophytes. One is listed on Valsa, one on the thallus of Castagnia, and two species (Z. enormis Pat. and Z. cubensis H. and Pat.) on the alga Stypocaule. These thallus-inhabiting forms, however, are markedly different from the present species.

\section{Sphaeropsoidales}

Phyllosticta bonduc, sp. nov.--Spots indefinite, large, starting usually at edge or apex and progressing over the whole leaflet. Pycnidia numerous, black, scattered, ostiolate, about $160-190 \mu$ in diameter. Wall about $\mathrm{I} 7 \mu$ thick, ostiole large, irregular. Conidiophores simple, hyaline, arising from sides and base of the pycnidium. Conidia hyaline, I-celled, oblong, $2 \mathrm{I} \times 4 \mu$, somewhat irregular in shape.

On Caesalpinia bonduc, Guanica, 360 (type).

This fungus is quite distinct from Phyllosticta guanicensis.

UNIVERSITY OF ILLINOIS

URBANA, ILlinoIS 

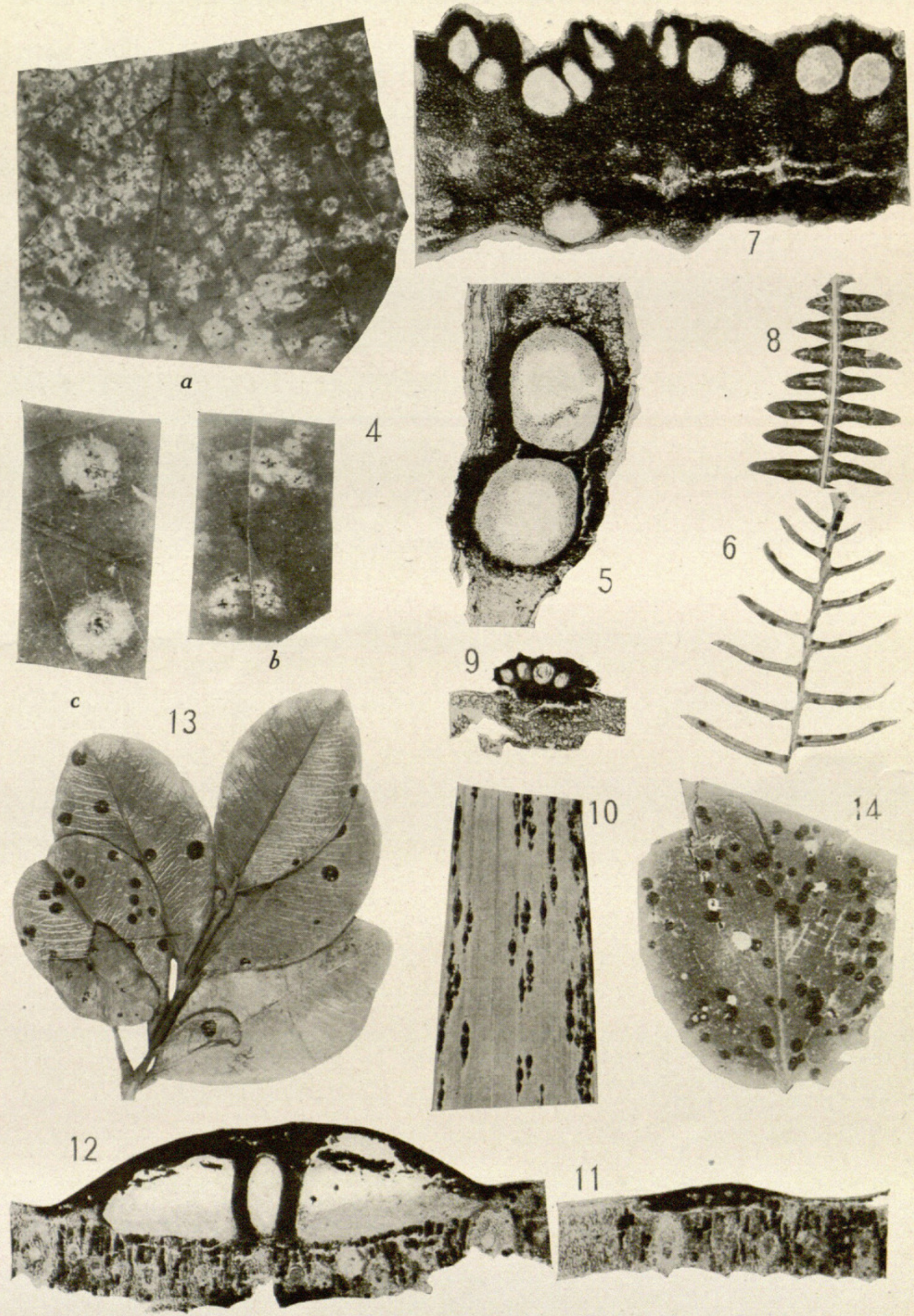


\section{$2 \mathrm{BHL}$ Biodiversity Heritage Library}

Stevens, Frank Lincoln. 1920. "Dothidiaceous and Other Porto Rican Fungi." Botanical gazette 69(3), 248-257. https://doi.org/10.1086/332638.

View This Item Online: https://www.biodiversitylibrary.org/item/109453

DOI: https://doi.org/10.1086/332638

Permalink: https://www.biodiversitylibrary.org/partpdf/224553

\section{Holding Institution}

Missouri Botanical Garden, Peter H. Raven Library

\section{Sponsored by}

Missouri Botanical Garden

\section{Copyright \& Reuse}

Copyright Status: Public domain. The BHL considers that this work is no longer under copyright protection.

This document was created from content at the Biodiversity Heritage Library, the world's largest open access digital library for biodiversity literature and archives. Visit BHL at https://www.biodiversitylibrary.org. 